\title{
STRATEGI PENGEMBANGAN PRODUK JIPANG BERBASISKAN PELATIHAN MANAJEMEN USAHA DAN PEMASARAN YANG KREATIF PADA UKM BUMDES DESA WONOKETRO JETIS PONOROGO
}

\author{
Titi Rapini, Naning Kristiyana, Adi Santoso, Fery Setyawan \\ Universitas Muhammadiyah Ponorogo \\ Email: nrafakristi@gmail.com
}

\begin{abstract}
Kegiatan ini bertujuan kondisi mitra hampir sama dengan kebanyakan UKM yang ada di desa lain, yakni mengalami beberapa permasalahan sehingga sulit untuk bisa berkembang. Industri kuliner jipang merupakan salah satu usaha milik BUMDes Desa Wonoketro, sedangkan desa Wonoketro itu sendiri memiliki hasil alam utama yakni padi, serta hasil tani berupa jagung dan kedelai. Sedangkan untuk bidang usaha mitra itu sendiri berupa jasa persewaan molen dan industri kuliner berupa jipang. Berdasarkan informasi yang digali dari pengurus, permasalahan yang dihadapi oleh mitra setidaknya ada empat hal, yakni: kurangnya analisa dan pengembangan potensi desa; belum kuatnya manajemen organisasi yang digunakan; lemahnya aspek administrasi dan manajemen keuangan; serta belum maksimalnya strategi pemasaran yang digunakan. Aspek modal yang selama ini menjadi salah satu masalah penting bagi sebuah badan usaha sebenarnya kurang berlaku bagi mitra, karena mitra mendapat dukungan modal yang cukup besar dari penyertaan modal dari desa maupun dari pemerintah kabupaten. Dalam mengatasi permasalahan ini, kami berusaha memberikan solusi dengan membidik aspek Sumber Daya Manusia (SDM). SDM menjadi salah satu aspek penting dalam sebuah organisasi karena SDM itulah yang menjalankan aspek lain dari sebuah organisasi. Kami berusaha menguatkan SDM organisasi mitra dengan memberikan beberapa program seperti pemberian pelatihan manajemen usaha, pelatihan pemasaran usaha mitra industri kuliner jipang demi menguatkan SDM dan marketing usaha industri Jipang milik BUMDes.
\end{abstract}

Keywords: SDM, manajerial usaha, pemasaran usaha

\section{ANALISIS SITUASI}

Desa Wonoketro dahulu tidak seluas saat ini, karena dahulu terdiri dari 2 (dua ) wilayah perdukuhan yaitu Dukuh Wonoketro dan Dukuh Jintap, yang mana dahulu kedua dukuh tersebut berdiri sendiri-sendiri, dan baru kira-kira tahun 1918 kedua dukuh tersebut digabungkan menjadi satu desa yaitu Desa Wonoketro. Secara geografis Desa Wonoketro merupakan salah satu desa yang berada di wilayah pusat Kecamatan Jetis, sehingga merupakan jalur poros antar desa dan antar kecamatan bahkan antar kabupaten dengan luas 132,35 Ha.

Secara administratif, Desa Wonoketro terletak di wilayah Kecamatan Jetis Kabupaten Ponorogo dengan posisi dibatasi oleh wilayah desa-desa tetangga. Di sebelah utara berbatasan dengan sungai
Keyang. Di sebelah barat berbatasan dengan Desa Josari Kecamatan Jetis. Di sisi selatan berbatasan dengan Desa Turi dan Desa Jetis Kecamatan Jetis, sedangkan di sisi timur berbatasan dengan Desa Tegalsari Kecamatan Jetis. Jarak tempuh Desa Wonoketro ke ibu kota kecamatan adalah $0,5 \mathrm{~km}$, yang dapat ditempuh dengan waktu sekitar 2-3 menit. Sedangkan jarak tempuh ke ibu kota kabupaten adalah $10 \mathrm{~km}$, yang dapat ditempuh dengan waktu sekitar 20 menit.

Tingkat kemiskinan di Desa Wonoketro termasuk tinggi. Dari jumlah 645 KK di atas, sejumlah 295 KK tercatat sebagai pra sejahtera; $177 \mathrm{KK}$ tercatat keluarga sejahtera I; $115 \mathrm{KK}$ tercatat keluarga sejahtera II; $55 \mathrm{KK}$ tercatat keluarga sejahtera III; 3 KK sebagai sejahtera III plus. Jika KK golongan pra-sejahtera dan KK golongan I digolongkan sebagai KK golongan miskin, 
maka lebih 50\% KK Desa Wonoketro adalah keluarga miskin. Secara geografis Desa Wonoketro merupakan salah satu desa yang berada di wilayah pusat Kecamatan Jetis, sehingga merupakan jalur poros antar desa dan antar kecamatan bahkan antar kabupaten dengan luas 132,35 Ha.

Tingkat pendapatan rata-rata penduduk Desa Wonoketro sangat rendah. Secara umum mata pencaharian warga masyarakat Desa Wonoketro dapat teridentifikasi ke dalam beberapa sektor yaitu pertanian, jasa/perdagangan, pegawai dan lain-lain. Berdasarkan data yang ada, masyarakat yang bekerja di sektor pertanian berjumlah 615 orang, yang bekerja disektor jasa berjumlah 256 orang, dan bekerja di sektor lain-lain 354 orang. Dengan demikian jumlah penduduk yang mempunyai mata pencaharian berjumlah 1.225 orang.

Wilayah Desa Wonoketro terdiri dari

2 Dusun yaitu: Dusun Jintap dan Dusun Wonoketro, yang masing-masing dipimpin oleh seorang kepala dusun atau kamituwo. Posisi kasun menjadi sangat strategis seiring banyaknya limpahan tugas desa kepada aparat ini. Dalam rangka memaksimalkan fungsi pelayanan terhadap masyarakat di Desa Wonoketro, dari dua dusun tersebut terbagi menjadi 4 Rukun Warga (RW) dan 12 Rukun Tetangga (RT). Keberadaan Rukun Tetangga (RT) sebagai bagian dari satuan wilayah pemerintahan Desa Wonoketro memiliki fungsi yang sangat berarti terhadap pelayanan kepentingan masyarakat wilayah tersebut, terutama terkait hubungannya dengan pemerintahan pada level di atasnya. Dari kumpulan Rukun Tetangga inilah sebuah Padukuhan (Rukun Warga; RW) terbentuk. Berdasarkan RPJMDes Desa Wonoketro, diketahui bahwa tingkat pendapatan rata-rata penduduk Desa Wonoketro sangat rendah. Secara umum mata pencaharian warga masyarakat Desa Wonoketro dapat teridentifikasi ke dalam beberapa sektor yaitu pertanian, jasa/perdagangan, pegawai dan lain-lain.
Berdasarkan data yang ada, masyarakat yang bekerja di sektor pertanian berjumlah 615 orang, yang bekerja disektor jasa berjumlah 256 orang, dan bekerja di sektor lain-lain 354 orang. Dengan demikian jumlah penduduk yang mempunyai mata pencaharian berjumlah 1.225 orang. Berikut ini adalah tabel 6 yang menunjukkan jumlah penduduk berdasarkan mata pencaharian.

Tabel 6. Mata Pencaharian dan Jumlahnya

\begin{tabular}{llcc}
\hline No & Mata Pencaharian & Jumlah & $\begin{array}{c}\text { Prosen } \\
\text { tase }\end{array}$ \\
\hline 1 & Pertanian & 615 orang & $50,2 \%$ \\
\hline \multirow{3}{*}{ Jasa/ Perdagangan } & 1. Jasa Pemerintahan & 98 orang & $8 \%$ \\
& 2. Jasa Perdagangan & 86 orang & $7 \%$ \\
& 3. Jasa Angkutan & 26 orang & $2,1 \%$ \\
& 4. Jasa Ketrampilan & 15 orang & $1,2 \%$ \\
& 5. Jasa lainnya & 31 orang & $2,5 \%$ \\
\hline 3 & Sektor lain & 354 orang & $28,9 \%$ \\
\hline \multirow{2}{*}{ Jumlah } & 1.225 & $100 \%$ \\
\hline
\end{tabular}

Dengan melihat data di atas maka angka pengangguran di Desa Wonoketro masih cukup tinggi. Berdasarkan data lain dinyatakan bahwa jumlah penduduk usia 2055 yang belum bekerja berjumlah 276 orang dari jumlah angkatan kerja sekitar 1.505 orang atau kira - kira $18 \%$ dari jumlah angkatan kerja yang ada. Angka-angka inilah yang merupakan kisaran angka pengangguran di Desa Wonoketro.

Dalam rangka meningkatkan perekonomian masyarakat desa, maka sesuai dengan program pemerintah Kabupaten Ponorogo, yakni OVOP (One Village One Product) maka dibentuklah Badan Usaha Milik Desa (BUMDes) Anugrah Jaya. BUMDes itu sendiri memiliki arti sebagai badan usaha yang keseluruhan atau sebagian besar modalnya dimiliki oleh desa melalui penyertaan langsung yang berasal dari kekayaan desa yang dipisahkan guna mengelola asset, jasa pelayanan, dan usaha lain semaksimal mungkin dengan tujuan kesejahteraan masyarakat (Ridlwan, 2014).

Titi Rapini - Strategi Pengembangan ProdukJipang Berbasiskan Pelatifan Manajemen Usaha dan Pemasaran yang Keatif Pada VKM BUMDes Desa Wonoketro Jetis Ponorogo 
Pemerintah desa harus mampu menggerakkan perekonomian dengan upayaupaya efektif penggerakan aktivitas-aktivitas ekonomi masyarakat desa. Kesiapan pemerintah tidak hanya berpusat pada penerimaan keuangan desa, tapi lebih kearah memberdayakan perekonomian masyarakat desa (Herry, 2015).

Adapun bidang usaha yang dimiliki oleh BUMDes Anugrah Jaya adalah jasa persewaan molen dan produksi salah satu makanan ringan yaitu jipang. Meski telah berdiri selama dua tahun, akan tetapi perkembangan BUMDes belum bisa dikatakan baik. Terbukti produksi jipang hanya berjalan 4 bulan saja, padahal alokasi modal yang diberikan kepada lembaga cukup besar (penyertaan modal dari Pemerintah sebesar Rp 25.000.000,-). Berdasarkan informasi yang didapatkan, setidaknya ada beberapa permasalahan yang dihadapi oleh mitra:

Minimnya analisa pengurus BUMDes dalam hal pemberdayaan potensi desa.

a. Lemahnya manajemen organisasi yang digunakan oleh pengurus.

b. Lemahnya kemampuan pemasaran produk yang dihasilkan.

Berdasarkan permasalahan diatas kami mencoba memberikan solusi dengan memperbaiki kualitas SDM. Menurut Damingun (2017), peranan SDM sangat menentukan maju atau tidaknya sebuah organisasi dalam menghadapi berbagai dinamika bisnis yang ada. Dalam hal ini, kondisi SDM di organisasi mitra masih dianggap belum kuat dalam hal manajerial dan administrasi. Selain itu, produk yang pernah diproduksi yakni makanan ringan jipang tidak bisa dilanjutkan produksinya, karena permasalahan pemasaran. Untungnya, kami mencoba memperkenalkan pelatihan manajemen usaha dan pelatihan pemasaran industri kuliner Jipang.

Produksi jipang milik BUMDes Wonoketro ini sudah 3 bulan terakhir ini tidak produksi lagi yaitu antara Januari sampai April 2019 dikarenakan penjualan semakin lama semakin menurun pada akhir tahun 2018. Persaingan di pasar sangat tinggi baik produk sejenis maupun produk pengganti. Pengelolaan manajemen tidak berjalan karena tidak ada pembukuan / administrasi penjualan dan akuntansi.

\section{METODE PELAKSANAAN}

Solusi yang ditawarkan pada Pengabdian Masyarakat industri kuliner jipang yang memungkinkan untuk dilaksanakan, berikut ini rencana kegiatan :

1. Melakukan pendampingan dan sharing untuk mengevaluasi pengelolaan usaha industri kuliner jipang milik BUMDes Wonoketro.

2. Mengadakan pelatihan manajemen pengelolaan usaha UKM industri jipang.

3. Pendampingan kinerja manajer industri kuliner jipang pasca pemberian pelatihan dan workshop.

4. Mengadakan pelatihan strategi pemasaran usaha industri kuliner jipang, dengan promosi melalui media teknologi informasi digital : Whatshapp, Twitter, Facebook, marketplace.

Dapat pula tujuan dari kegiatan pengabdian ini adalah manajer dan pengelola industri kuliner jipang mampu mengembangkan usaha melalui produk jipang sehingga dapat memberikan dampak positif dalam meningkatkan profit dan berkemajuan. Serta terciptanya branding usaha jipang yang berkarakter produk hasil Desa Wonoketro. Dan dalam jangka panjangnya di harapkan dapat survive dan membantu mengurangi jumlah pengangguran yang ada di Desa Wonoketro. Secara detail tujuan yang ditargetkan adalah sebagai berikut:

a. Pemahaman dan kesadaran SDM pengelola industri jipang.

b. Terbentuknya mental wirausaha pada

Titi Rapini - Strategi Pengembangan ProdukJipang Berbasiskan Pelatifan Manajemen Usaha dan Pemasaran yang Keatif Pada VKM BUMDes Desa Wonoketro Jetis Ponorogo 
manajer dan SDM industri kuliner jipang.

c. Manajer dan SDM industri kuliner jipang memiliki kemampuan yang baik dalam hal pemasaran konvensional dan e-marketing.

d. Peningkatan pengetahuan manajer dan SDM industri kuliner jipang dalam melakukan pengelolaan dan pengembangan usaha makanan.

Metode pengembangan yang akan dilaksanakan merupakan sebuah rangkaian tahapan yang disusun secara sistematis, berikut adalah metode pelaksanaan yang akan dilaksanakan :

1. Melakukan persiapan program Pengabdian Masyarakat di Desa Wonoketro, Jetis Ponorogo

Kegiatan ini merupakan tahap awal yang dilakukan untuk menyamakan persepsi dan membuat perencanaan secara bersama dengan anggota tim dan pihak yang terkait dalam pelaksaan program pengabdian yang akan dilakukan di Desa Wonoketro.

2. Pembuatan handout manajemen pengelolaan usaha industri kuliner jipang

Pembuatan handout ini sebagai pegangan peserta pelatihan pengelolaan usaha manajer industri jipang yang akan diberikan kepada mitra (seluruh pengelola UKM jipang).

3. Melakukan sosialisasi antara mitra dan pengabdian untuk koordinasi pelaksaan program Pengabdian Masyarakat

Tim pengabdian bersama dengan melibatkan mahasiswa akan melakukan sosialisasi program kepada mitra pengabdian masyarakat dengan tujuan agar tercipta model pelatihan dan pendampingan yang disepakati antara tim pengabdian dengan mitra pengabdian.

4. Melakukan pendampingan dan sharing untuk mengevaluasi pengelolaan usaha industri jipang

Pendampingan ini untuk melihat sejauh mana pengelola usaha industri jipang milik BUMDes termotivasi untuk melakukan pengelolaan secara serius, selain itu kegiatan ini merupakan proses identifikasi dan pemetaan terkait konsep untuk pelatihan selanjutnya.

5. Melakukan pelatihan manajemen pengelolaan BUMDES oleh tim ahli (tim pengabdian)

Kegiatan ini merupakan proses pelatihan manajemen oleh tim dengan tujuan untuk memberi pengetahuan dan keterampilan kepada pengelola / manajer industri jipang agar mereka ke depan dapat melakukan pengelolan usaha secara profesional.

6. Melakukan pendampingan tim pengabdian

Tim pengabdian akan melakukan pendampingan untuk melihat perkembangan industri kuliner jipang untuk menyelesaikan permasalahanpermasalahan dan solusi setelah mitra mengimplementasikan pelatihan yang diberikan.

7. Melakukan evaluasi keseluruhan terhadap pelaksanaan kegiatan pengabdian antara tim pengabdian dengan mitra.

Kegiatan ini dilakukan untuk mengukur sebarapa puas dan berpengaruh UKM jipang yang diberikan pembekalan teknis pemasaran dan manajemen usaha untuk perkembangan usaha industri jipang.

\section{HASIL DAN PEMBAHASAN}

A. Pelaksanaan Kegiatan

Pelatihan dalam kegiatan IbM Internal ini mencapai keberhasilan karena dukungan berbagai pihak yang terkait dan mau bekerjasama dengan baik, yaitu pihak mitra (sasaran) dalam hal ini pengurus BUMDes Wonoketro sebagai pemilik UKM jipang dan kerjasama kami dengan BUMDes Winong serta anggota komunitas Bukalapak sebagai tutor teknis $e$ commerce. Keberhasilan kerjasama juga terjadi karena akar permasalahan diperoleh dari pihak mitra sendiri. Pelaksanaan kegiatan dilakukan di bulan September 
2018 pada tanggal 14-16 September 2019. Kegiatan dilaksanakan dalam bentuk pendaftaran produk ke marketplace dan strategi merk serta packing serta sosialisasi pengantar bisnis dengan beberapa kali tatap muka. Pelaksanaan kegiatan dilakukan di BUMDes Winong Kec. Jetis Ponorogo.

B. Penyelesaian Permasalahan

\section{Permasalahan Pertama}

Sumber Daya Manusia pada UKM jipang rendah sehingga harus ditingkatkan dalam pelatihan manajemen usaha ini dengan dibekali wawasan tentang manajemen dan pengantar bisnis. Mengenalkan POAC : Planning, Organising, Actuating dan Controling.

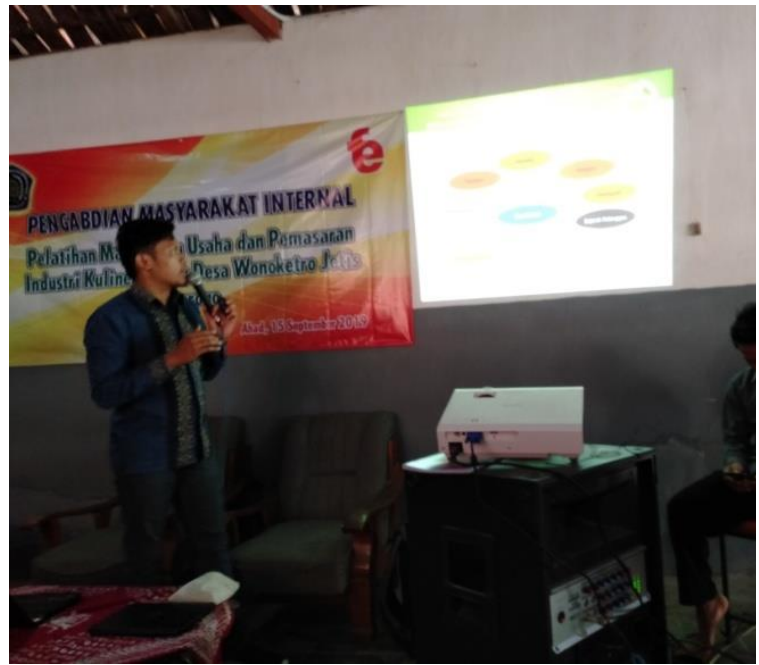

Lingkungan eksternal usaha UKM jipang seperti pesaing, revolusi industri 4.0 , selera konsumen yang saat ini, yang perlu harus diperhatikan UKM jipang.
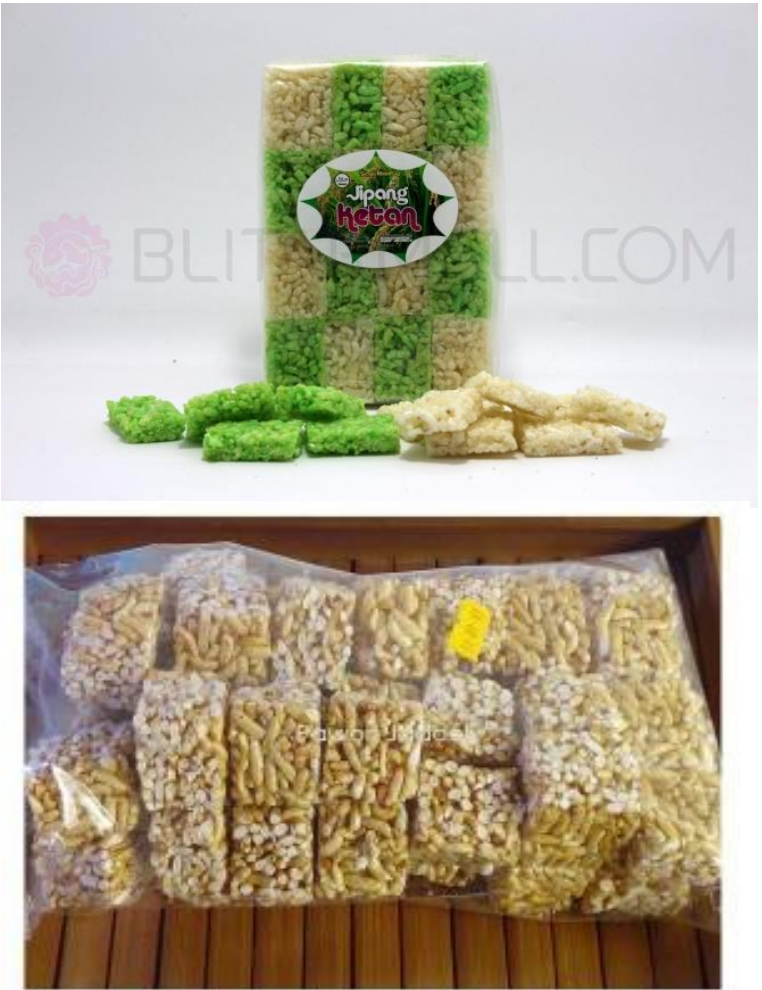

Marketing mix, strategi merk dan packing produk dapat mengemas produk dengan karakter keunikan tersendiri sehingga produk jipang Wonoketro bisa dikenal kekhasan jipangnya oleh masyarakat. Kemasan produk lebih bervariatif sesuai perkembangan produk saat ini. Misalnya produk jipang dibuat bulat-bulat kecil, bentuk love, bentuk lonjor, atau bentuk yang lain.

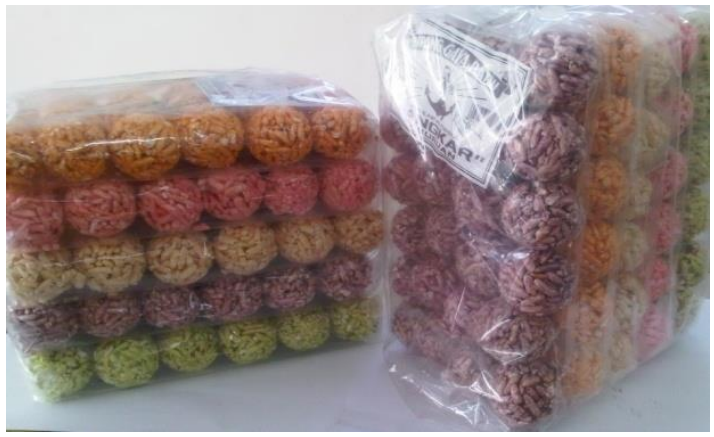

Titi Rapini - Strategi Pengembangan ProdukJipang Berbasiskan Pelatifan Manajemen Usaha dan Pemasaran yang Keatif Pada VKM BUMDes Desa Wonoketro Jetis Ponorogo 


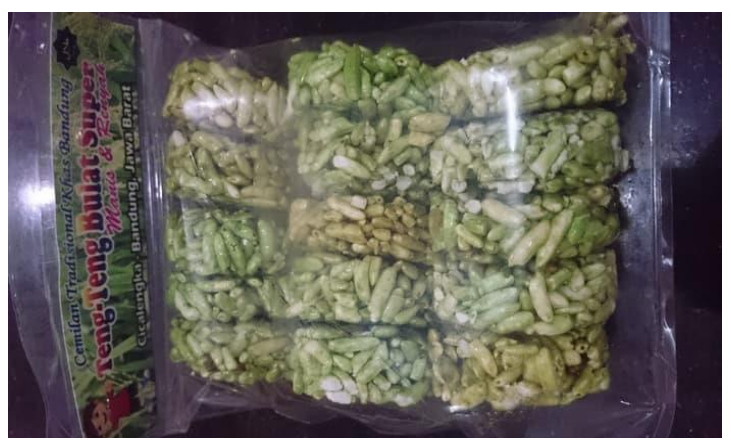

2. Permasalahan Kedua

Strategi pemasaran produk untuk meningkatkan penjualan pada UKM jipang, melalui marketing mix dan market place. Pemahaman tentang marketing mix yaitu Product, Place, Prize dan Promotion disampaikan dengan metode presentasi dan contoh kasus sehingga lebih mudah dipahami. 1) Produk jipang Wonoketro harus dikemas secara variatif mulai dari bentuk, biasanya hanya kotak persegi panjang di buat variatif bulat atau lonjong, 2) Place : Packing produk jipang dikemas dengan brand jipang Wonoketro sehingga menarik pembeli, sesuai model packing makanan ringan saat ini

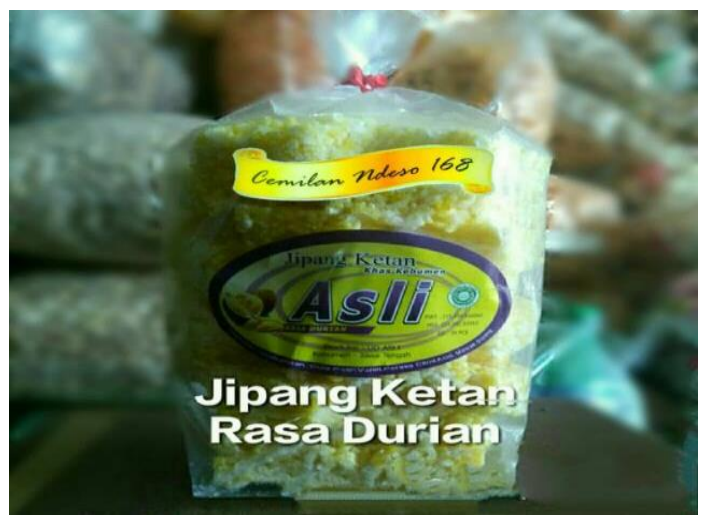

dan strategi disitribusi produk jipang minimal ada di wilayah Ponorogo mulai dari desa sampai kota, artinya UKM siap menyediakan barangnya, 3) Harga produk jipang Wonoketro sudah sesuai harga pasar dan terjangkau karena produk makanan kecil yang bisa dikonsumsi semua golongan masyarakat, 4) Promotion: setelah produk dapat diperbaiki dengan strategi point 1 , maka promosi produk jipang diarahkan untuk dijual melalui online seperti market place Bukalapak, Lazada, dan lain-lain. Seluruh peserta diberikan pelatihan pendaftaran produk ke Bukalapak, mulai dari mengisi identitas produk sampai pada pelayanan penjualan jika ada pembeli .

\section{Permasalahan Ketiga}

Peningkatan profit usaha jipang sehingga lebih maju dan tetap survive di masa yang akan datang dengan cara meningkatkan penjualan. Peningkatan penjualan bisa dilaksanakan jika ada pembeli yang banyak, hal ini tergantung promosi yang dilakukan oleh UKM jipang sehingga mampu meningkatakan penjualan, salah satu strateginya dengan promosi lewat marketplace Bukalapak ini.

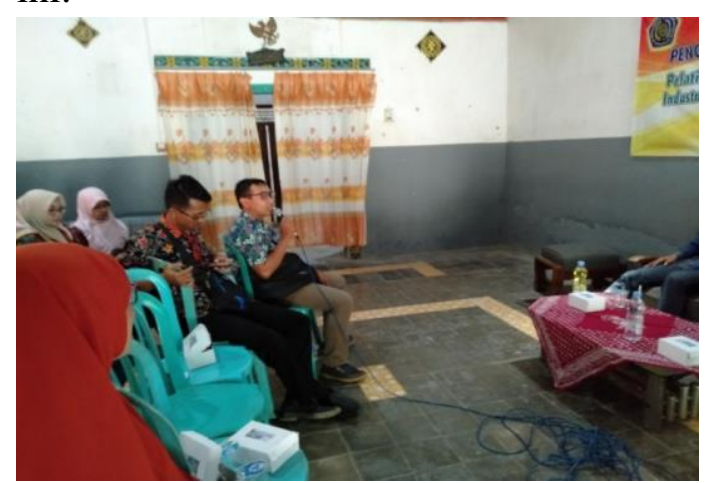

Peningkatan penjualan yang berdampak pada pendapatan usaha kemudian dikurangi dengan biaya operasional usaha akan dapat menghasilkan laba. Semakin tinggi pendapatan dan biaya operasional yang dapat dikendalikan maka akan mendapatkan laba yang tinggi.

\section{KESIMPULAN}

1. Mitra dalam hal ini UKM jipang diberikan pemahaman dan wawasan penyuluhan tentang manajemen, pengantar bisnis, dan strategi pemasaran untuk membantu meningkatkan usaha agar lebih bergairah dan produktif, 
pemahaman tentang peluang bisnis dari modal usaha BUMDes.

2. Sumber Daya Manusia pada UKM jipang rendah sehingga harus ditingkatkan dalam pelatihan manajemen usaha ini dengan dibekali wawasan tentang manajemen dan pengantar bisnis. Mengenalkan POAC : Planning, Organizing, Actuating dan Controling. Lingkungan eksternal usaha UKM jipang seperti pesaing, revolusi industri 4.0 , selera konsumen yang saat ini, yang perlu harus diperhatikan UKM jipang.

3.Startegi pemasaran produk untuk meningkatkan penjualan pada UKM jipang, melalui marketing mix dan market place. Pemahaman tentang marketing mix yaitu Product, Place, Prize dan Promotion disampaikan dengan metode presentasi dan contoh kasus sehingga lebih mudah dipahami. Seluruh peserta diberikan pelatihan pendaftaran produk ke Bukalapak, mulai dari mengisi identitas produk sampai pada pelayanan penjualan jika ada pembeli .

4. Peningkatan profit usaha jipang sehingga lebih maju dan tetap survive di masa yang akan datang dengan cara meningkatkan penjualan. Peningkatan penjualan bisa dilaksanakan jika ada pembeli yang banyak, hal ini tergantung promosi yang dilakukan oleh UKM jipang sehingga mampu meningkatakan penjualan, salah satu strateginya dengan promosi lewat marketplace Bukalapak ini.

5. Saran yang dapat kami sampaikan berdasar hasil pengabdian ini, pengabdian pada UKM jipang ini masih bisa berlanjut sejalan proses pendampingan pada UKM sudah sesuai arahan dari pelatihan tersebut apa belum. Apabila masih terjadi banyak kendala tim pengabdian bisa dapat melakukan program pengabdian ini sampai pada keberhasilan variasi produk, packing produk dan promosi produk melalui Bukalapak tersebut.

\section{DAFTAR PUSTAKA}

Tjiptono, F.(2015).Aplikasi Manajemen Pemasaran. Yogyakarta:Andi Ofset

Griffin, R.W \& Ronald J.E. (2007). Bisnis

Edisi Bahasa Indonesia, Edisi kedelapan, Jilid 1. Jakarta: Penerbit Erlangga

Sadono, S.(2017). Pengantar Bisnis. Jakarta: Kencana,

Nickels, W.G., James M.M., \& Susan M. M., (2005). Understanding Business. 7th Edition. New York: McGraw-Hill

Kotler, P \& Kevin L.K. (2012). Marketing Management 14th edition. New Jersey:Prentice Hall

Kotler, P \& Gary A. (2010). Principles of Marketing $13^{\text {th }}$ edition. New Jersey:Prentice Hall

Pramudiana, Y, Maya, A \& Nurafni, R. (2015). Marketing Plan. Bandung:Alfabeta 